\title{
Reconstructing fluid history: an integrated approach to timing fluid expulsion and migration on the Carboniferous Derbyshire Platform, England
}

DOI:

10.1144/GSL.SP.1998.144.01.12

Link to publication record in Manchester Research Explorer

Citation for published version (APA):

Hollis, C. (1998). Reconstructing fluid history: an integrated approach to timing fluid expulsion and migration on the Carboniferous Derbyshire Platform, England. In Geological Society Special Publication (pp. 153-159). Geological Society . https://doi.org/10.1144/GSL.SP.1998.144.01.12

Published in:

Geological Society Special Publication

\section{Citing this paper}

Please note that where the full-text provided on Manchester Research Explorer is the Author Accepted Manuscript or Proof version this may differ from the final Published version. If citing, it is advised that you check and use the publisher's definitive version.

\section{General rights}

Copyright and moral rights for the publications made accessible in the Research Explorer are retained by the authors and/or other copyright owners and it is a condition of accessing publications that users recognise and abide by the legal requirements associated with these rights.

\section{Takedown policy}

If you believe that this document breaches copyright please refer to the University of Manchester's Takedown Procedures [http://man.ac.uk/04Y6Bo] or contact uml.scholarlycommunications@manchester.ac.uk providing relevant details, so we can investigate your claim.

\section{OPEN ACCESS}


Geological Society, London, Special Publications

Reconstructing fluid history: an integrated approach to timing fluid expulsion and migration on the Carboniferous Derbyshire Platform, England

Cathy Hollis

Geological Society, London, Special Publications 1998; v. 144; p. 153-159

doi:10.1144/GSL.SP.1998.144.01.12

Email alerting

service

Permission

request

Subscribe click here to receive free email alerts when new articles cite this article

click here to seek permission to re-use all or part of this article

click here to subscribe to Geological Society, London, Special Publications or the Lyell Collection

\section{Notes}

Downloaded by Catherine Elizabeth Hollis on 7 August 2009 


\title{
Reconstructing fluid history: an integrated approach to timing fluid expulsion and migration on the Carboniferous Derbyshire Platform, England
}

\author{
CATHY HOLLIS \\ Department of Geology and Petroleum Geology, University of Aberdeen, Meston Building, \\ Kings College, Aberdeen AB9 $2 U E, U K$ \\ Present address: Badley Ashton and Associates Ltd, Winceby House, Winceby, Horncastle, \\ Lincolnshire LN9 6PB, UK
}

\begin{abstract}
Galena-sphalerite-baryte-fluorite mineralization and non-economic reserves of liquid hydrocarbon and bitumen are hosted on the Derbyshire Platform within Lower Carboniferous limestone which was deposited during Variscan back-arc extension. The limestone also hosts a sequence of burial calcite cements, precipitated dominantly in crosscutting and refractured extensional vein systems, which typically follow Caledonian-Variscan trends. The calcite cements are often intergrown with galena, sphalerite, baryte and fluorite as well as bitumen, whilst epifluorescence reveals hydrocarbon inclusions. Paragenetic relationships, in conjunction with geochemical results, permit definition of a precise timing for mineralization and hydrocarbon emplacement, and modelling of the source, composition and migration pathways of the mineralizing fluids.
\end{abstract}

The Derbyshire Platform of northern England hosts lead-zinc-fluorine-barium mineralization within Lower Carboniferous limestone, and forms part of the Pennine Orefield. This mineralization has been studied extensively (Ineson \& Ford 1982; Coleman et al. 1989; Ixer \& Vaughan 1993), but the timing of mineralization has never been successfully established (Ford 1968; Coomer \& Ford 1975; Ineson \& Mitchell 1972). This study is based upon detailed petrographical and geochemical analysis of vein calcite cements from the Derbyshire Platform, which were coprecipitated with the galena, fluorite, baryte and galena. Conclusions can be drawn on the distribution of mineralization and an integrated model for fluid expulsion and migration during mineralization is presented.

\section{Structural development of the Derbyshire Platform}

The Derbyshire Platform developed within the Pennine Basin in a back-arc extensional regime north of the developing Variscan Orogen (Fraser et al. 1990). Depositional platforms developed upon areas which were underlain by stable, Lower Palaeozoic basement whilst the surrounding basins (typically developed on the hanging wall of NE-SW and NW-SE trending Caledonian basement faults, Fig. 1) subsided more rapidly (Leeder 1988). Within the study area, carbonate sedimentation occurred upon the Derbyshire Platform during the Dinantian
(Fig. 2), on the western margin of the Derbyshire-East Midlands Platform. This platform sourced sediment to the surrounding Edale, Staffordshire and Widmerpool Basins (Fig. 1), in which sedimentation was dominantly of marine shales within turbidite-fronted fluvio-deltaic systems (Kelling \& Collinson 1992; Fig. 2). As extension waned, thermal sag subsidence increasingly influenced sedimentation in the Namurian and Westphalian, and fluvio-deltaic systems continued to prograde southwards and progressively buried the Derbyshire Platform (Guion \& Fielding 1988). A compressional regime developed in the late Westphalian with the onset of the Variscan Orogeny, culminating in basin inversion (Leeder 1988; Smith \& Smith 1989).

\section{Techniques}

Burial calcite cements were described from polished sections of Asbian and Brigantian limestone (Fig. 2) which were sampled from across the Derbyshire Platform (Hollis \& Walkden 1996). Petrographical description of calcite cements and mineral assemblages within intergranular pore systems and small ( $<5 \mathrm{~cm}$ wide) fracture systems employed plane light, cathodoluminescence $(\mathrm{CL})$ and epifluorescence (blue light) techniques. The cements were further categorized using stable isotope and trace element geochemistry (electron and ion probe microanalysis), and fluid inclusion microthermometry. Full analytical details are given in Hollis (1995). 


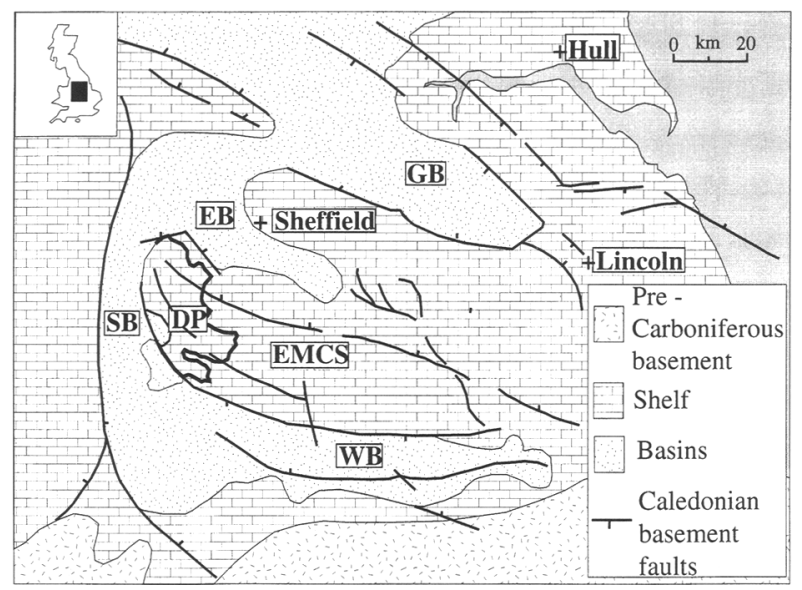

Fig. 1. Dinantian palaeogeography of the Derbyshire-East Midlands carbonate platform and surrounding basins (after Walkden \& Williams 1991). DP, Derbyshire Platform: EMCS, East Midlands carbonate platform; EB, Edale Basin; SB, Staffordshire Basin; WB, Widmerpool Basin; GB, Gainsborough Basin.

\begin{tabular}{|c|c|c|}
\hline Series & Stage & $\begin{array}{c}\text { Study } \\
\text { intervals }\end{array}$ \\
\hline \multirow{4}{*}{ 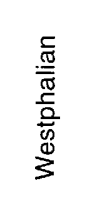 } & $D$ & \multirow{4}{*}{ 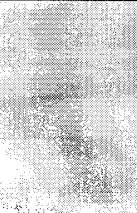 } \\
\hline & C & \\
\hline & B & \\
\hline & $A$ & \\
\hline \multirow{6}{*}{ 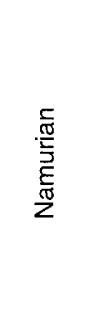 } & Yeodonian & \multirow{4}{*}{$\frac{x}{2}=$} \\
\hline & Marsdenian & \\
\hline & Kinderscoutian & \\
\hline & Sabdenian & \\
\hline & Arnsbergian & \multirow{2}{*}{$\begin{array}{l}\text { Interval of } \\
\text { study in } \\
\text { basins }\end{array}$} \\
\hline & Pendelian & \\
\hline \multirow{6}{*}{ 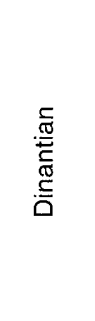 } & Brigantian & \multirow{2}{*}{$\begin{array}{l}\text { Interval of } \\
\text { study on } \\
\text { platform }\end{array}$} \\
\hline & Asbian & \\
\hline & Holkerian & \\
\hline & Arundian & \\
\hline & Chadian & \\
\hline & Courceyan & \\
\hline
\end{tabular}

Fig. 2. Stratigraphic column for the Derbyshire Platform and surrounding area showing intervals studied.

\section{Paragenesis}

Carboniferous limestone and dolomitized beds on the Derbyshire Platform host economic galena and fluorite mineralization, with baryte and calcite gangue and minor sphalerite. The mineralization has previously been classified as Mississippi Valley-type, since it is carbonatehosted and has a low temperature $\left(<200^{\circ} \mathrm{C}\right)$ origin (Ixer \& Vaughan 1993). The Derbyshire Platform also hosts uneconomic hydrocarbon reserves (Ewbank et al. 1993). These occur typically as solid bitumen (e.g. Parnell et al. 1994), and less commonly as liquid hydrocarbon within intergranular pore systems and along fractures. Seven separate phases of vein calcite cementation (Zones 3A-4D) have been identified on the platform, based upon cross-cutting and petrographical characteristics (Hollis \& Walkden 1996; Fig. 3). Fluid inclusions demonstrate an overall increase in homogenization temperature $\left(57.3^{\circ} \mathrm{C}-200^{\circ} \mathrm{C}\right)$ and salinity $(4.4-23.1 \mathrm{wt} \%$ $\mathrm{NaCl})$ within these successive cement phases (Fig. 4a). Fluorite, baryte, galena and sphalerite are increasingly intergrown with Zone 3B-4C calcite along fractures, such that Zone $4 \mathrm{C}$ cements are intergrown with these minerals in most veins (Fig. 3). Hydrocarbon inclusions are recognized within Zone $3 \mathrm{~B}-4 \mathrm{~B}$ calcite cements, whilst Zone 4D cross-cuts bitumen.

\section{Fluid, major ion and hydrocarbon source}

Trace element analysis suggests that the best potential source of major ions for mineralization 


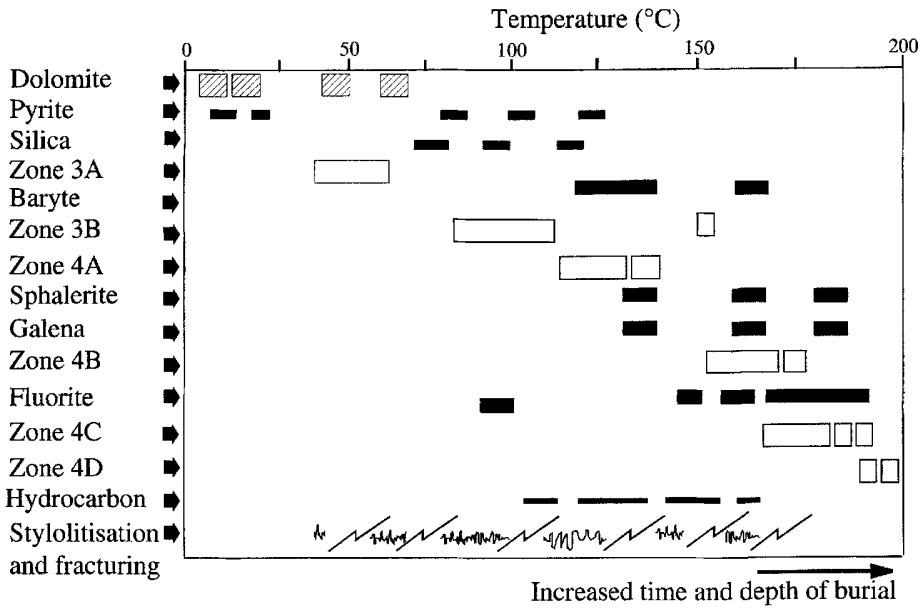

Fig. 3. Paragenetic sequence for late burial cements on the Derbyshire Platform.
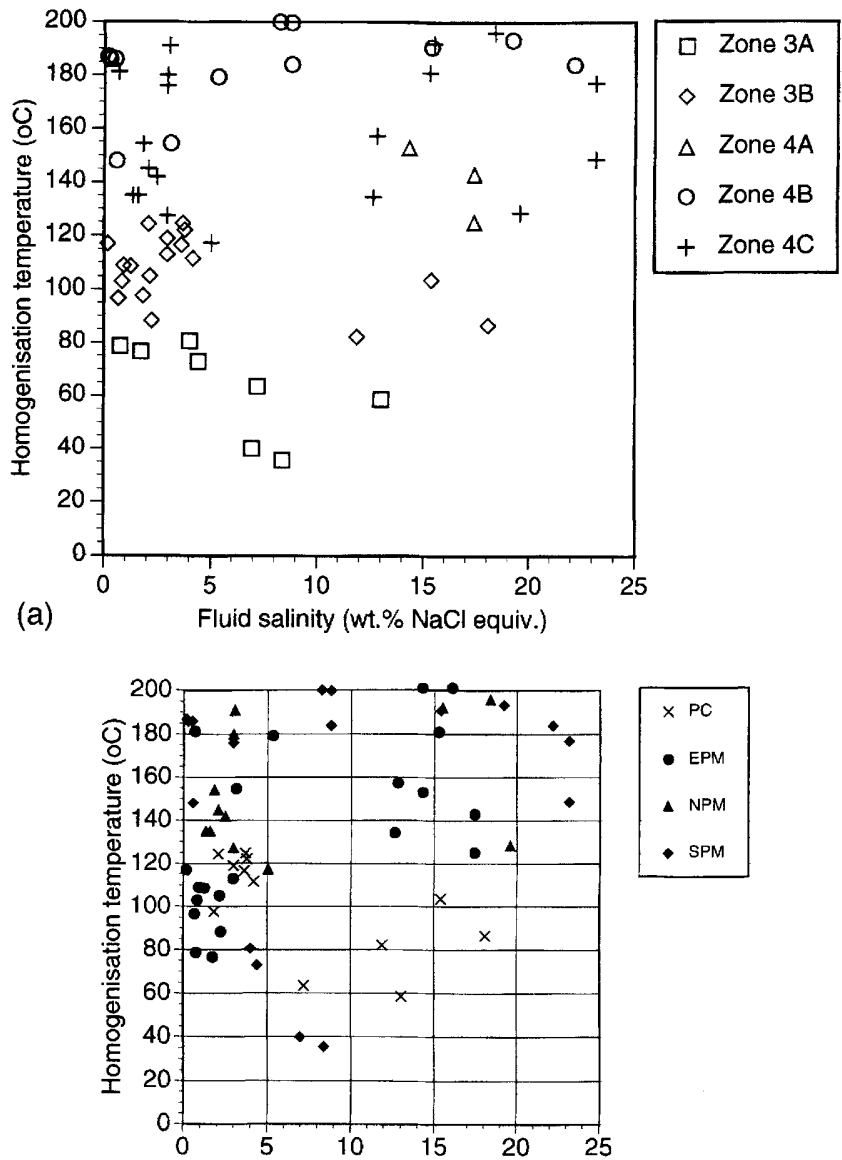

(b) Fluid salinity (wt. \% $\mathrm{NaCl}$ equivalent)

Fig. 4. Homogenization temperatures and fluid salinities for (a) Zone $3 \mathrm{~A}-4 \mathrm{C}$ cements and (b) according to platform position. 
on the Derbyshire Platform were DinantianWestphalian sediments within the Edale, Staffordshire and Widmerpool Basins, as well as the Gainsborough Basin to the north-east (Jones \& Plant 1989; Hollis 1995). Hydrocarbon was probably sourced from Dinantian-Namurian pro-delta mudstones within these basins (Ewbank et al. 1993; Hollis 1995). Fluid temperatures and salinities for Zone $3 \mathrm{~A}-4 \mathrm{D}$ cements are consistent with this (Fig. 4a), and fluid compositions $\left(\delta^{18} \mathrm{O}_{\text {water }}\right.$ up to $12 \%$ SMOW; Hollis 1995$)$ suggest mineralization from a highly evolved basinal brine. Paragenetic variations in $\delta^{18} \mathrm{O}_{\text {mineral }}$ and $\delta^{13} \mathrm{C}_{\text {mineral }}$ values strongly suggest that expulsion of fluids was coincident with hydrocarbon generation and clay mineral dehydration (Hollis \& Walkden 1996), and trace element release to fluids was probably strongly controlled by both these mechanisms.

The low volumes of hydrocarbon on the platform imply that only minor volumes of some elements (e.g. $\mathrm{Pb}, \mathrm{Zn}, \mathrm{F}$ ) could have been transported onto the platform within petroleum phases (e.g. Parnell 1990). Elements such as $\mathrm{Pb}$ may be highly soluble as acetate complexes (Manning 1986), but this is unlikely to have been an effective transport mechanism under reducing conditions (Giordano 1993) which would have occurred during mineralization. It is likely that transport of major ions $(\mathrm{F}, \mathrm{Zn}$, $\mathrm{Pb}, \mathrm{Ba}$ ) for mineralization was principally by inorganic (e.g. chloride and fluoride) complexing of ions within aqueous phases. Fluid-rock ratios were often low enough for equilibration of fluid $\delta^{13} \mathrm{C}, \delta^{18} \mathrm{O}$ and trace elements with relatively high distribution coefficients, with the host limestone (Hollis 1995).

\section{Fluid migration pathways}

Galena-sphalerite-fluorite-baryte mineralization on the Derbyshire Platform is concentrated principally along east-west trending strike-slip faults and extensional joint and fracture systems. Less commonly these minerals form replacement deposits adjacent to faults. Calcite typically cements strike-slip and extensional faults and NE-SW and NW-SE trending extensional joints and fractures, and can be correlated with interparticle pore fill cements (Hollis \& Walkden 1996). There is no unequivocal evidence of changes in fluid composition or temperature towards the platform margins. However, vein calcite cements from the eastern margin of the field area typically contain the highest concentrations of trace elements, the most extreme isotopic values and the highest fluid inclusion tempera- tures (Fig. 4b). This suggests a strong east-west component to fluid migration, focused along Caledonian basement faults which connect the Widmerpool and Gainsborough Basins to the Derbyshire Platform.

\section{Timing of mineralization}

An overall increase in fluid temperatures and salinity within successive cements (Fig. 4a) implies that cementation took place under increasingly deeper burial conditions. Changes in the petrographical and geochemical characteristics of cements on the Derbyshire Platform often reflect diagenetic events within the basins. Since biomarkers indicate that hydrocarbon was sourced from Namurian mudrocks within the basins (Ewbank et al. 1993), the clearest manifestations of this are the petroleum inclusions within Zone 3B-4B calcite. A relative increase in the concentration of most elements within Zone 3B and Zone 4A calcite demonstrates that trace element release from basinal shales had been initiated, probably through thermal decarboxylation of organic matter and the dehydration of hydrous clays (Fig. 5). Most striking, however, is that all measured trace element concentrations reach a maximum within Zone $4 \mathrm{C}$ calcite, despite distribution coefficients which vary by more than a factor of 10 . Correspondingly, this cement is intergrown most commonly with other minerals, implying that it was precipitated during the major phase of mineralization on the platform. This strongly suggests that mineralization took place principally at the deepest burial depth, and two major controls can be highlighted.

\section{Drive for fluid migration}

The concentration of cements along fault and fracture systems implies a continued tectonic control on fluid movement throughout the period of cementation. Diagenetic evidence favours the release of fluids during progressive burial of the Derbyshire Platform and the surrounding basins in the Namurian-Westphalian. Nevertheless, waning movement along extensional fault systems during this period would have permitted the release of increasingly minor volumes of fluid. The development of overpressures within the basins is not fully modelled, although they are likely to have occurred (Hollis \& Walkden 1996). It is unlikely, however, that without corresponding movement along faults, rupture of overpressured compartments 

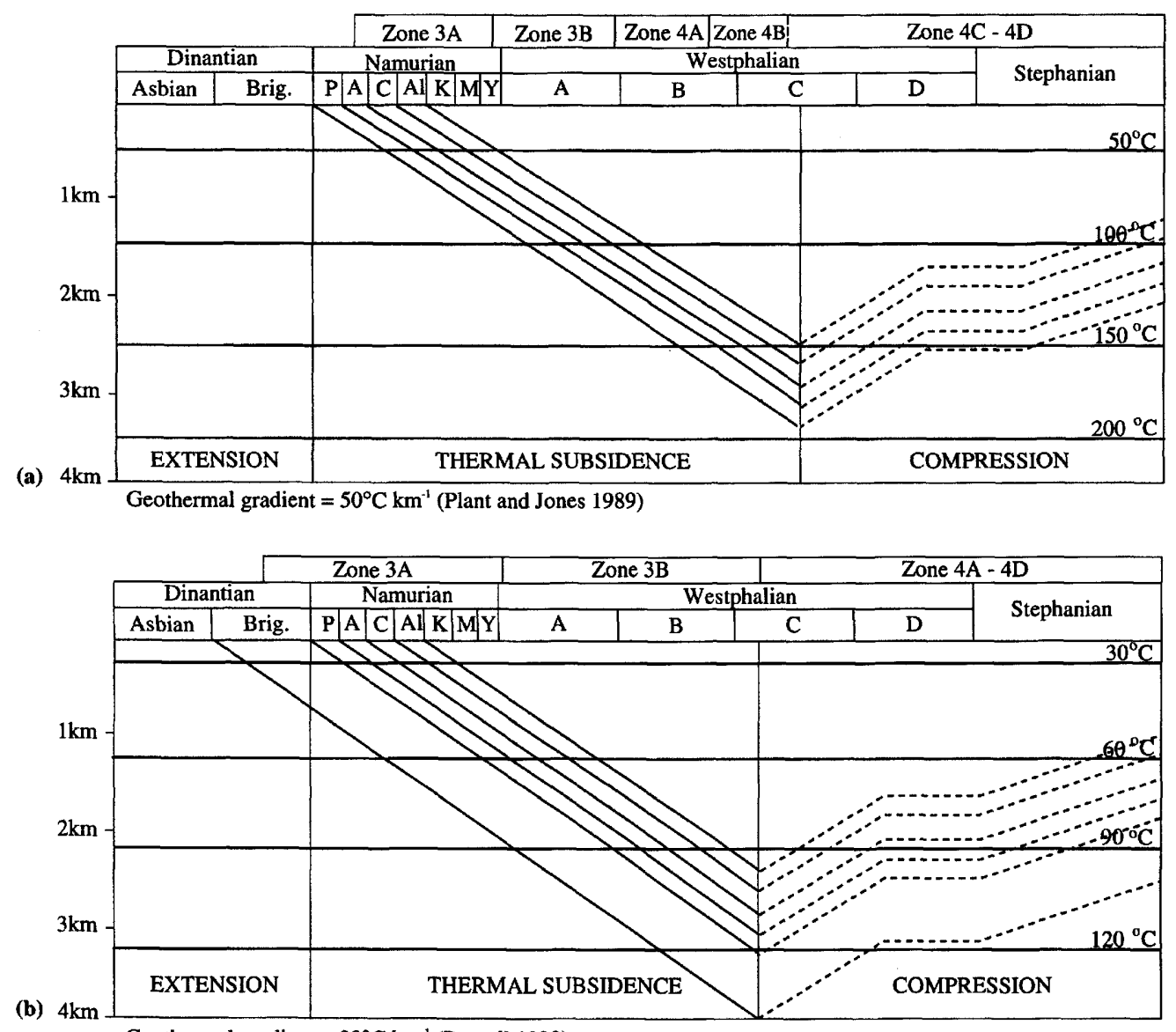

Geothermal gradient $=30^{\circ} \mathrm{C} \mathrm{km}^{-1}$ (Russell 1992)

Fig. 5. Burial history curves for (a) Edale Basin and (b) Staffordshire and Widmerpool Basins (after Coleman et al. 1989; Russell 1992) showing approximate timings of cementation.

could have generated sufficient drive for fluid expulsion (e.g. Giles et al. 1997). Reactivation of Caledonian and extensional fault systems with the onset of the Variscan Orogeny and compressional tectonism in the late Westphalian (Fig. 5) would have created a renewed tectonic drive. This permitted the expulsion and migration of large volumes of fluid from the basins onto the Derbyshire Platform, culminating in the most intense phase of mineralization.

\section{Release of trace elements}

The basins surrounding the Derbyshire Platform reached maximum burial depths of approximately $3 \mathrm{~km}$ in the late Westphalian. Different geothermal gradients have been invoked, however, with an elevated gradient of $50^{\circ} \mathrm{C} \mathrm{km}^{-1}$ in the Edale Basin and a more normal gradient $\left(30^{\circ} \mathrm{C} \mathrm{km}^{-1}\right)$ proposed for the Staffordshire and Widmerpool Basins (Coleman et al. 1989; Russell 1992). This implies that although hydrocarbon and trace elements were being released from Namurian shales, at temperatures above $\sim 90^{\circ} \mathrm{C}$, in the Edale Basin during much of the Westphalian (Fig. 5a), Namurian shales in the other basins were only undergoing thermal decarboxylation and thermal maturation prior to and during maximum burial (Fig. 5b). This suggests, therefore, that a greater volume of trace elements were available for mineralization later in the burial history.

\section{Emplacement mechanisms}

With renewed tectonism, fluids would have been expelled rapidly from the basins along major 
fault systems. Once emplaced on the Derbyshire Platform they would have been squeezed into well-developed fracture systems, which permitted fluid circulation within the host limestone. Faults and fractures terminate against Namurian shales which onlap the Derbyshire Platform, suggesting that these shales provided a vertical barrier to fluid movement during mineralization. Sulphide and sulphate mineralization probably took place during mixing of the trace-element charged basinal brines and sulphide-rich fluids, which are thought to have been platform-derived (Coleman et al. 1989). In addition, mixing of fluids from different basins may have initiated mineralization and resulted in the range of fluid temperatures and salinities measured during fluid inclusion analysis. Calcite cementation is thought to have also been controlled by fluid mixing, as well as by a decrease in pressure and a change in $\mathrm{pH}$ between the basins and the platform. It is unlikely that there was a rapid change in fluid $\mathrm{pH}$ from the basins onto the Derbyshire Platform (e.g. Quirk 1987), since isotope data suggest that fluid-rock interaction and fluid buffering were well underway prior to fluid expulsion from the basins (Hollis \& Walkden 1996). Fluorite mineralization could have taken place by the breakdown of fluoride complexes (Hollis 1995), the stability of which is often controlled by calcite precipitation (Nordstrom \& Jenne 1977).

\section{Conclusions}

1. The coexistence of diagenetic calcite cements, hydrocarbon and galena-fluorite-barytesphalerite mineralization implies a common timing.

2. Mineralizing fluids were expelled from the clastic basins surrounding the Derbyshire Platform along Caledonian-Variscan faults by seismic pumping.

3. The coexistence of most minerals, and the highest concentrations of trace elements, within Zone $4 \mathrm{C}$ calcite implies that these cements were precipitated during the main phase of mineralization. Fluid inclusion results suggest that Zone $4 \mathrm{C}$ was precipitated during maximum burial.

4. The main drive for fluid expulsion and migration is interpreted to be the reactivation of fault systems during the Variscan Orogeny. The greatest concentration of trace elements for mineralization are anticipated to have been available at this time.

5. Mineralization was probably initiated by fluid mixing, although a range of controls is likely to have been important.
This research was conducted under NERC research studentship, GT/91/GS/01. Gordon Walkden is thanked for his supervision during this work. Stable isotope analysis was conducted at the Scottish Universities Research and Reactor Centre. Ion microprobe and electron probe microanalysis was undertaken at Edinburgh University. Jim Hendry is thanked for reading an earlier version of this manuscript which also benefited from the useful suggestions of two anonymous reviewers. John Parnell generously helped with the formatting and collation of the manuscript for this volume.

\section{References}

Coleman, T. B., Jones, D. G., Plant, J. A. \& Smith, K. 1989. Metallogenic models for carbonate-hosted (Pennine- and Irish-style) mineral deposits. In: Plant, J.A. \& Jones, D. G. (eds) Metallogenic models and exploration criteria for buried carbonate-hosted ore deposits - a multidisciplinary study in Eastern England. British Geological Survey, Keyworth and Institute of Mining and Metallurgy, London. 123-134.

Coomer, P. G. \& Ford, T. D. 1975. Lead and sulphur isotope ratios of some galea specimens from the south Pennines and north Midlands. Mercian Geologist, 5, 291-304.

Ewbank, G., Manning, D. A. C. \& Aвbott, G. D. 1993. An organic geochemical study of bitumens and their potential source rocks from the South Pennine Orefield, Central England. Organic Geochemistry, 20, $579-598$.

Ford, T. D. 1968. Epigenetic mineralization of the carbonizing limestone. In: Sylvester-BradLey, P. C. \& Ford, T. D. (eds) Geology of the East Midlands. University of Leicester, 73-93.

Fraser, A. J., Nash, D. F, Steele, R. P. \& Ebdon, C. C. 1990. A regional assessment of the intra-Carboniferous play of Northern England. In: Brooks, J. (ed.) Classic Petroleum Provinces. Geological Society, London, Special Publications, 50, 417-440.

Giles, M. R., Mcnutt, J. F., De Jong, J. C., Kukla, P., Indrelid, S. L., Kraaijevanger, H. \& Beynon, G. V. 1997. Overpressures and their prediction: a review. In: Hendry, J., Carey, P., Parnell, J., Ruffell, A. \& Worden, R. (eds) Geofluids $I$, Second International Conference on fluid evolution, migration and interaction in rocks. Extended abstract. p. 218

Giordano, T. H. 1993. Metal transport in ore solutions by organic ligand complexation. In: PARnell, J., Ruffell, A. \& Moles, N. (eds) Geofluids '93, Contributions to an International Conference on fluid evolution, migration and interaction in rocks. Extended abstract, 413-416.

Guion, P. \& Fielding, C. 1988. Westphalian A and B sedimentation. In: BesLy, B. M. \& Kelling, G. (eds) Sedimentation in a synorogenic basin complex; the Upper Carboniferous of NW Europe. Blackie, Glasgow, 153-177. 
Hollis, C.E. 1995. Burial diagenetic events, hydrocarbon emplacement and mineralization in Dinantian limestones of Northern Britain. $\mathrm{PhD}$ thesis, University of Aberdeen.

- \& WALKDEN, G. M. 1996. The use of burial diagenetic calcite cements to determine the controls upon hydrocarbon emplacement and mineralization on a carbonate platform, Derbyshire, England. In: Strogen, P. Somerville, L. D. \& Jones, G. L. L. (eds) Recent Advances in Lower Carboniferous Geology. Geological Society, London, Special Publications, 107, 35-49.

Ineson, P. R. \& Mitchell, J.G. 1972. Isotopic age determinations on clay minerals from lavas and tuffs of the Derbyshire Orefield. Geological Magazine, 109, 501-512.

— \& Ford, T. D. 1982, The South Pennine Orefield: its genetic theories and eastwards extension. $\mathrm{Mer}$ cian Geologist, 8, 285-304.

IXER, R. A. \& VAUGHAN, D.J. 1993. Lead-zinc-fluoritebarite deposits of the Pennine, North Wales and the Mendips. In: Pattrick, R, \& Polya, D. (eds) Mineralization in the British Isles. Chapman and Hall, London, 355-411.

Jones, D. G. \& Plant, J. A. 1989. Geology of shales. In: Plant, J. A. \& Jones, D.G. (eds) Metallogenic models and exploration criteria for buried carbonate-hosted ore deposits - a multidisciplinary study in Eastern England. British Geological Survey, Keyworth, and Institute of Mining and Metallurgy, London, 65-94

Kelling, G. \& Collinson, J.D. 1992, Silesian. In: Duff, P. McL. D. \& Sмith, A. J. (eds) The Geology of England and Wales. Geological Society, London, 239-263.

Leeder, M. R. 1988. Recent developments in Carboniferous geology: a critical review with implications for the British Isles and NW Europe. Proceedings of the Geologists' Association, 99, 73 - 100.

ManNing, D.A.C. 1986. Assessment of the role of organic matter in ore transport processes in low temperature base metal systems. Transactions of the Institute of Mining and Metallurgy, 95, B195-B200.

Nordstrom, D. K.\& Jenne, E. A. 1977. Fluorine solubility in selected geothermal waters. Geochimica et Cosmochimica Acta, 41, 175-188.

Parnell, J. 1990. Metal enrichments in organic material as a guide to ore mineralization. In: PARnell, J., Lianjun \& Chengming, C. (eds) Sediment Hosted Mineral Deposits. Special Publication of the International Association of Sedimentologists, 11, 183-192.

Carey, P.F. \& Bottrell, S. 1994. The occurrence of authigenic minerals in solid bitumens. Journal of Sedimentary Research, A64, 95-100.

Quirk, D. 1987. Structure and genesis of the South Pennine Orefield. $\mathrm{PhD}$ thesis, University of Leicester.

Russell, M.A. 1992. The organic geochemistry and thermal maturity of the Pennine Carboniferous Basin. PhD thesis, University of Aberdeen.

Smith, K. \& Smith, N. J. P. 1989. Deep Geology. In: Plant, J.A. \& Jones, D. G. (eds) Metallogenic models and exploration criteria for buried carbonate - hosted ore deposits - a multidisciplinary study in Eastern England. British Geological Survey, Keyworth, and Institute of Mining and Metallurgy, London, 53-64.

Walkden, G. \& Williams, D, 1991. The diagenesis of the late Dinantian Derbyshire-East Midlands carbonate shelf, central England. Sedimentology, 38, 643-670. 